\title{
Detection of Bromide Ions in Water Samples with a Nanomolar Detection Limit using a Potentiometric Ion-selective Electrode
}

\author{
Lijuan Kou ${ }^{1, *}$ and Rongning Liang ${ }^{2}$ \\ ${ }^{1}$ School of Enology, Binzhou Medical University, Yantai, 264003, P. R. China. \\ ${ }^{2}$ Key Laboratory of Coastal Environmental Processes and Ecological Remediation, Yantai Institute of \\ Coastal Zone Research (YIC), Chinese Academy of Sciences (CAS), Shandong Provincial Key \\ Laboratory of Coastal Zone Environmental Processes, Yantai YICCAS, Yantai, 264003, P. R. China. \\ *E-mail: 1jkou@yic.ac.cn
}

doi: $10.20964 / 2019.02 .02$

Received: 9 April 2018 / Accepted: 9 August 2018 / Published: 5 January 2019

This paper presents a robust potentiometric solid-contact ion-selective electrode (ISE) for the rapid detection of bromide ions ( $\left.\mathrm{Br}^{-}\right)$in water samples. The sensing membrane contains poly (vinyl chloride) (PVC), bis(2-ethylhexyl)sebacate (DOS) and ionophore without a lipophilic ion exchanger, and provides good potential responses for $\mathrm{Br}^{-}$in the range of 0.010 to $1.0 \mu \mathrm{M}$. The calibration curve demonstrates detection limits of $2.0 \times 10^{-9} \mathrm{~mol} / \mathrm{L}(3 \sigma)$ for bromide ions. Moreover, compared with previously reported $\mathrm{Br}^{-}$-selective ISEs, the proposed ISE offers remarkably improved sensitivity for the detection of bromide and provides better selectivity coefficients for $\mathrm{HPO}_{4}{ }^{2-}, \mathrm{CH}_{3} \mathrm{COO}^{-}, \mathrm{NO}_{3}^{-}$, and $\mathrm{Cl}^{-}$. The proposed sensor is successfully applied for the practical determination of $\mathrm{Br}^{-}$in real water samples.

Keywords: ISEs; Bromide ions; potentiometric; solid contact

\section{FULL TEXT}

(C) 2019 The Authors. Published by ESG (www.electrochemsci.org). This article is an open access article distributed under the terms and conditions of the Creative Commons Attribution license (http://creativecommons.org/licenses/by/4.0/). 